\title{
Environmental Regulation in the Pulp and Paper Industry: Impacts and Challenges
}

\author{
Patrik Söderholm ${ }^{1} \cdot$ Ann-Kristin Bergquist ${ }^{2} \cdot$ Kristina Söderholm $^{3}$
}

Published online: 1 November 2019

(C) The Author(s) 2019

\begin{abstract}
Purpose of Review In this article, we review existing research addressing how environmental regulations have influenced the pulp and paper industry. These regulations appear in different forms and designs and address air and water pollution as well as climate change. The paper devotes particular attention to how various regulations have affected sustainable technological change and the prospects for inducing deep emission reductions without jeopardizing industrial competitiveness and future investments. Recent Findings Experiences from key pulp and paper regions, not least the Nordic countries, suggest that gradually tightening performance standards have contributed to radical reductions in emissions, e.g., chlorine compounds and biological oxygen demanding agents, and without imposing excessive compliance costs. This outcome can largely be attributed to how the regulations have been designed - and implemented - in practice, as well as to the presence of efficient and legitimate institutions. Long-term emission reduction targets, in combination with extended compliance periods and trustful firm-regulator relationships, contributed to radical technological innovation and permitted radical emission reductions without excessive compliance costs. The development of alternative bleaching technologies is an apt example. In contrast, the impact of carbon pricing schemes, including the EU emissions trading scheme, on carbon dioxide emissions reductions and related technological change in the pulp and paper industry has however been modest. Self-regulation, certification, and community pressure have exerted relatively modest influences on the environmental performance of the industry.

Summary Important avenues for future research are identified. These include the following: (a) comparative research on how policy mixes in various countries have influenced environmental compliance and innovation; processes; (b) future studies of environmental regulations, their design and implementation, in emerging pulp and paper producing countries, not least China; and (c) research on how environmental regulations can affect ongoing restructurings in the industry towards a broader palette of products in biorefineries.
\end{abstract}

Keywords Environmental regulation $\cdot$ Pulp and paper industry $\cdot$ Competitiveness $\cdot$ Innovation $\cdot$ Pollution $\cdot$ Climate change

\section{Introduction}

The environmental impacts of the pulp and paper industry have been significant throughout the twentieth century and are still

This article is part of the Topical Collection on Forest Policy, Economics, and Social Research

Patrik Söderholm

patrik.soderholm@1tu.se

1 Economics Unit, Luleå University of Technology, SE-971 87 Lulea, Sweden

2 Unit of Economic History, Centre for Environmental and Resource Economics (CERE), Umeå University, SE-907 87 Umea, Sweden

3 History Unit, Luleå University of Technology, SE-971 87 Lulea, Sweden serious. This resource- and capital-intensive industry contributes to many existing environmental problems, including global warming, human toxicity, ecotoxicity, photochemical oxidation, acidification, nutrification, and the generation of solid wastes [1, 2]. Increased concerns over such environmental issues, not least air and water pollution and climate change, have led to the introduction of new as well as more stringent environmental policies.

These policies include both regulations in the form of performance standards (emission limit values) [3], technology requirements $[4,5]$, as well as various incentive-based instruments such as taxes/charges and tradable emission allowances $[6,7]$. In addition to these, it is also important to consider the role of voluntary approaches [8••] and self-regulation [9], which often forms part of corporate sustainability strategies. Occasionally, market demand, community pressure, and/or the threat of imposing stringent regulations in the future could 
be central drivers for efforts to improve environmental performance at the company level.

Environmental regulations influence the current practices and the future opportunities of the pulp and paper industry, not least since the industry is highly export-dependent and competes in global markets. In fact, while regulations are necessary for reducing the environmental impacts of current operations, lengthy permitting processes and inflexible standards could also lead to increased uncertainty about the future business opportunities, and even hamper the incentives to pursue more radical, sustainable technological change [10••]. Notably, for the industry and transport sectors, the transition to a bio-based economy largely hinges on the development of so-called advanced biorefineries, which based on flexible intake of various bio-based materials permit the production of large quantities of bulk products along with various highvalue products, such as specialty chemicals and materials $[11,12]$. This development is particularly relevant for the incumbent industry, which, instead of using the forest raw material exclusively for the production of pulp and paper products, also could produce low-carbon transportation fuels (e.g., biodiesel), green chemicals (e.g., organic acids), and various substances used in the construction industry (e.g., ligninconcrete mixes) $[13 \bullet \cdot]$. This suggests, thus, that stringent environmental regulations can pose both opportunities as well as threats for achieving future environmental improvements.

The purpose of this article is to synthesize the existing research addressing how environmental regulations have influenced the pulp and paper industry so far. We devote particular attention to how such regulations have affected sustainable technological change as well as the prospects for achieving deep emissions reductions without jeopardizing industrial competitiveness and future investments. Indeed, the pulp and paper industry is an interesting case in this respect. Experiences from developed countries, not least the Nordics, suggest that such green transitions have been possible while at the same time avoiding excessive compliance costs and permitting increased production [e.g., 3, 14••]. This outcome, the present article illustrates, can largely be attributed to how regulations have been designed - and implemented - in practice, as well as to the existence of efficient and legitimate institutions, including trustful relationships between regulatory authorities and industry representatives.

In the article, we highlight research on environmental policies that currently regulate - or have regulated — emissions into air and water in the pulp and paper industry. This not only permits an emphasis on key policy design and implementation issues but also implies that we do not address studies that $e x$ ante assess the impacts of hypothetical policy changes, e.g., [15]. As shown below, the empirical research reviewed in this paper has often had a strong focus on discharges into water of biological oxygen demanding (BOD) agents, phosphorous, and chlorine compounds. Some studies also address policies regulating emissions into air, e.g., sulfur dioxide and nitrogen oxides. Although the emphasis is on local environmental pollution, we also include references to the regulation of carbon dioxide emissions, including the European Union Emissions Trading Scheme (EU ETS). However, we do not discuss recent research explicitly addressing policies aiming at improved energy efficiency in the pulp and paper industry, e.g., energy taxes, information programs, and voluntary agreements (e.g., $[16,17])$. In addition, we do not discuss the impact of environmental enforcement and monitoring activities on compliance behaviour; a few empirical applications to the pulp and paper industry do exist (e.g., [18]).

Finally, geographically, there is a strong focus in the article on the pulp and paper industries in the developed world, in particular the Nordic and the North American countries. Occasionally, however, some contrasting cases from, for instance, other EU Member States and China are also included. This focus largely reflects the availability of relevant studies, not least in the light of our emphasis of ex post regulatory experiences. The environmental regulation of the Swedish and Finnish has gained significant research interest, also among several non-Nordic scholars. Other EU Member States are not well-researched, in part because the pulp and paper industry has been less dominant in these countries compared to the forest-rich Nordic countries.

The article proceeds as follows. In the next section, we outline some key conceptual points of departure for the review. The remainder of the article then discusses the empirical evidence on the roles of self-regulation and community pressure, the effectiveness of various types of environmental regulations and policy instruments, and the impact of environmental regulations on industrial competitiveness and technological change and innovation. The article ends with a discussion of key implications and some important avenues for future research.

\section{Conceptual Points of Departure}

The environmental regulation of natural resource-based industries, such as the pulp and paper sector, involves difficult trade-offs. While most pollution taxes and standards often will induce the adoption of incremental emission reductions, government regulators increasingly face the challenge of imposing emission reduction targets for the future that cannot be met by employing currently existing ("off-the-shelf") technologies $[19,20]$. In the latter setting, profound process changes are needed, and the chosen regulatory approach has to maintain strong, continuous incentives for emission reductions while at the same time taking into account the risk of excessive compliance costs for industry. In the short- to medium-term, there exists therefore a trade-off between stringent environmental policies on the one hand and competitiveness on the other 
$[10 \bullet, 21]$. This is a particular concern in the pulp and paper industry (and other sectors) that competes in global markets. Indeed, even though the global forest industries are likely to play an important role in the transition to a zero-carbon economy, climate policies (and other environmental regulations) are often perceived as a threat to industrial competitiveness. For instance, in the beginning of the 2000s, the European pulp and paper industry lobbied against the introduction of the EU ETS $[10 \bullet \cdot$.

The relationship between environmental regulation and industrial competitiveness has been the subject of considerable debate in the academic literature over the past two decades. Much of this discussion has centered on the so-called Porter hypothesis [22]. This hypothesis states that properly designed environmental regulations will (a) stimulate environmental innovation and technological change (the weak version of the hypothesis) and (b) increase not only the environmental performance but also the economic performance in terms of profits, productivity, etc., of industries (the strong version) [23]. For our purposes, it should be noted that empirical applications to the pulp and paper industry have gained a prominent place in this debate, and previous studies have investigated both the strong and the weak version of the Porter hypothesis (see further below).

Over the long run, a move towards sustainable industrial transformation requires that new and more environmentally benign technologies are developed and widely adopted. For this reason, regulatory approaches that stimulate technological change and that permit flexibility over time in identifying, developing, and demonstrating new technology will be of central interest in the transition towards deep emission reductions (e.g., [3, 24]). However, there appears to be meager evidence of one type of policy instrument being superior to others in terms of promoting sustainable technology choice and innovation. Specific policy designs, various implementation strategies, and institutional contexts, which typically have evolved over several decades, may matter just as much $[25,26]$. In fact, the entire setup and organization of the regulatory systems, e.g., negotiation and time strategies and trust, have proved to be decisive for the effectiveness of environmental regulations [e.g., 4, 27].

In the remainder of this article, we first briefly address the role of self-regulation and then cover environmental regulations in three contexts: (a) their effectiveness in terms of encouraging emission reductions; (b) their impacts on competitiveness and technological change; as well as (c) the importance of well-functioning institutions. This thematic structure of the paper implies that the same regulations may be discussed multiple times (but in different contexts). The paper identifies and discusses a number of prerequisites for an efficient and legitimate transition towards deep emission cuts in the pulp and paper industry.
Self-regulation, Certification, and Community Pressure

In the 1980s, self-regulation, based on codes of environmental management practice, emerged as an alternative to traditional government regulations [28, 29]. Through private or other non-governmental schemes, companies voluntarily commit to improve environmental management practices beyond regulatory compliance. In the global forest industries, such agreements have included, for instance, the U.S. Sustainable Forestry Standard Initiative (SFI), the international environmental management standard ISO 14001, and the Forest Sustainable Council Standard (FSC), among others [30].

The empirical evidence about the effectiveness of selfregulation on industrial environmental performance is however overall mixed [9, 31]. Some scholars have found that coregulation systems that include both voluntary private initiatives as well as mandatory state measures may hold particular benefits both to state and industry actors [32, 33]. Still, many scholars have been skeptical about the effectiveness of industry codes of conduct, and about whether these could be used as protection against more stringent standards [34].

The dominating stream of research has rather focused on examining why firms adopt voluntary standards and diffusion patterns $[35,36]$ rather than scrutinizing the impacts on environmental performance. For instance, Lennox and Nash [29] analyze self-regulatory programs in four different US industrial sectors and address the potential problem of adverse selection, i.e., that the more polluting companies tend to join voluntary programs. However, for the US pulp and paper industry, the results suggested the opposite; companies that had joined the (SFI) program in 1994 polluted less in 1996 compared to companies that had chosen not to participate.

A number of studies have investigated the impacts of the adoption of international ISO 14001 standards on environmental performance in industry (e.g., [30, 36]). However, although there exist several studies that investigate the role of self-regulation and the adoption of certification schemes in forestry [37-39], applications to the pulp and paper industry are surprisingly scarce. Gunningham and Sinclair [40] examine the adoption of ISO 14001 standards in the Australian pulp and paper industry and suggest that such a regulatory approach could impose unnecessary costs on businesses; it may even result in less, and not more, favorable environmental outcomes. Barla [41] investigates the adoption of the ISO 14001 standard in the pulp and paper industry of Quebec. By using monthly data for 37 plants over the period 1997-2004, he shows that this certification had modest impacts on environmental performance. In a recent study, Bergquist and Keskitalo [8••] compare the development of regulatory regimes in the Swedish forestry sector and the country's pulp and paper industry. The authors conclude that while the forestry sector was deregulated in the 1990s, and with preference 
given to self-regulation, the emissions from the pulp and paper industry continued to be regulated. Even though close to $100 \%$ of the industry's output has been manufactured under ISO 14001 and/or the European so-called EMAS scheme, CEOs in the Swedish pulp and paper industry perceived government regulation as the more significant driver for reduced emissions.

Finally, while previous research suggests that certification schemes have played a modest role for emission reductions in the pulp and paper industry, there are studies that emphasize the role of consumer demand and community pressure. Indeed, in Sweden, conflicts over pulp mills' emissions into air and water can be traced more than 100 years back in time [42]. The most prominent example, it is often argued, is the introduction of alternative bleaching technologies in northern Europe during the 1980s and 1990s. This process gained momentum in the mid-1980s after the U.S. Environmental Protection Agency detected dioxins downstream from pulp mills producing bleached pulp [43].

A number of studies argue that community pressure and green consumerism were key drivers in the transition to chlorine-free pulp production [44-47]. Popp et al. [44] conclude that in particular, the Nordic pulp and paper mills responded by launching the necessary development and modification processes well before any regulations were in place. Reinstaller [46] argues that the increase in green consumer demand in Europe was in turn related to the ability of various policy entrepreneurs, not the least Greenpeace, to link the pulp bleaching issue to already perceived environmental threats. In fact, other research suggests that the diffusion of alternative bleaching technologies in the South Asian and Australian pulp industries during the 1990s also benefitted from the actions of these non-governmental actors [48]. Nevertheless, the transfer of technology to South Asia was much helped by the presence of Nordic pulp technology firms in the region [48, 49]. In other words, environmental regulation, the argument goes, lagged behind, but was eventually encouraged by both public pressure and the availability of alternative bleaching technologies. Still, as noted in the next section, this conclusion has been challenged in more recent research, which instead emphasizes the importance of environmental regulation in accomplishing lower emissions of chlorinated organic compounds as well as stimulating innovation in alternative technologies, such as oxygen delignification and advanced batch cooking.

Pressures to improve environmental performance may also come from the capital market. In a study of the US pulp and paper industry, the author provides empirical support for the notion that the debt capital market view pollution-intensive industries to be high-risk investments since firms with poor environmental performance (in terms of the amount of toxic chemicals released to land, air and water) may face major liabilities in the future [50]. For this reason, the market applies an environmental risk premium to the cost of debt capital for the average firm in the US pulp and paper industry. As noted below, though, government regulations have typically had more significant impacts on environmental performance than the capital market.

\section{The Effectiveness of Environmental Regulations}

Since the advent of modern environmental policy, standardbased regulations have dominated over market-based instruments such as taxes and tradable emissions allowance schemes. In some instances, such as in the regulation of the North American pulp and paper industries, the standards have relatively often been technology- rather than performancebased $[4,5,43,51]$. By design, the technology-based standards provide no leeway to undertake other (low-cost) measures and could even force the adoption of suboptimal technologies. Instead, performance standards do provide such flexibility, which is essential due to the presence of firmregulator information asymmetries where mills typically know better than the regulator what it will cost to reduce emissions using various abatement measures (and/or a mix of several ones) [3]. This section begins with a discussion of the role of performance standards in regulating water and air pollution. We then devote specific attention to the heterogeneous development of alternative bleaching technologies in the USA and the Nordic countries, respectively. In this transition, the distinction between performance and technology standards was essential along with other important regulatory design issues. We end with a discussion of the impacts of regulations of carbon dioxide emissions.

\section{Performance Standards and Water and Air Pollution}

The use of performance standards has been the dominating regulatory approach for the Nordic pulp and paper industries. Empirical studies that have addressed the impact of such standards on emissions reductions tend to focus on water discharges, and they adopt both quantitative and qualitative methods. While the former approach can detect general patterns, the latter permits studies of the dynamics of regulatory implementation and industry responses at a greater depth. Quantitative studies in both Finland and Sweden confirm that performance standards have indeed affected discharges of BOD agents and phosphorous and chlorine compounds [52, 53]. Even though the actual discharges often have been well below the standards, the emission limit values nevertheless imposed binding constraints on the regulated emissions. One reason for this is that mills may be unable to perfectly monitor emissions and will therefore pollute below the standard in order to avoid the risk of non-compliance and any penalties 
that would follow from this. Brännlund and Löfgren [54] illustrate such rational behaviour in the empirical context of the Swedish pulp and paper industry (see also [55] for a related analysis using data for the US pulp and paper industry).

Furthermore, there is typically also a gradual tightening of these standards, and anticipation of more stringent regulatory conditions in the future. This result is confirmed in a number of case studies [3, 14••, 24, 26, 56-59]. The Swedish case studies in particular emphasize the important role of flexibility in compliance strategies. Even if the key regulatory authority in Sweden, the so-called Licensing Board of Environmental Protection, often advocated a particular abatement technology, its members emphasized that this should not be stipulated in the final regulatory conditions [3]. The pulp and paper mill had the possibility to use other methods if any shortcomings could be proved with the suggested technology and more effective methods could be developed. In this way, the Board maintained the regulatory strategy to permit flexibility in compliance strategies, while at the same time requiring emission levels to comply with the performance of best available technology (BAT). The Swedish case studies also illustrate the importance of using extended compliance periods [14••, $60 \bullet \bullet$. By allowing such intertemporal flexibility, thus reducing investment uncertainty and permitting companies to test various $R \& D$ and demonstration routes, the affected mills could accept the increased uncertainty associated with a more ambitious performance standard in the future. Moreover, long compliance periods also made it possible for companies to coordinate environmental and productive investments.

The conclusion that government regulations have constituted an important determinant of environmental performance in the pulp and paper industry gains supports also in North American studies. In one study using technology choice data for 686 paper mills in the USA [61], the authors find that more stringent air and water regulations had a positive impact on the adoption of abatement technologies. They also report that abatement and productive investment tend to be concentrated in the same years, thus implying that regulations permitting flexibility in terms of the timing of compliance ought to facilitate the process of environmental compliance. In another study, interviews with Canadian managers of pulp and paper companies confirm that government regulations have had a far more profound influence on environmental compliance than consumer demand and the financial markets [62].

Furthermore, previous studies emphasize that the engagement of the top-level management and the environmental education of employees and other in-house resources (e.g., R\&D capabilities) are key drivers of efficient responses to environmental regulations. These factors are discussed in two Canadian studies $[62,63]$ and in one recent, comparative study of pulp and paper firms in Finland, Germany, Sweden, and the USA [64•]. The latter study concludes that there appear to be important differences across firms in these countries in terms of their knowledge and ability to pursue changes in the production processes. Moreover, it also shows that the more stringent and transparent regulations in the Nordic countries compared to the USA did lead to significant environmental improvements already during the end of the 1980s.

Even though research on environmental regulation in pulp and paper industries outside North America and the EU Member States is quite scarce, it is worth noting that an increasing number of, in particular, Chinese studies have emerged during the last few decades $[65,66,67 \bullet]$. A study of the Chinese pulp and paper industry during the country's period of economic reform (1980s-1990s) has highlighted the small size of Chinese mills (e.g., [65]), which made it difficult to implement modern pollution control technologies developed in Europe or North America. Still, China now has the world's largest production of pulp and paper with modern technology. Some of the more recent research on China uses indices of eco-efficiency and investigates how these indices have developed with the introduction of stricter environmental regulations $[66,67 \bullet]$. Overall, the findings confirm that such regulations have induced significant environmental improvements, except for the case of carbon dioxide emission reductions where less progress has been made so far. These studies, though, devote very limited attention to the design and implementation of the relevant regulations.

While previous research confirms that performance standards have contributed to the adoption of new environmental technologies, the most significant influence has typically been reported with respect to end-of-pipe technologies, such as the activated sludge treatment. One reason for this could be that companies will typically find it difficult to anticipate upcoming regulatory decisions, thus making it difficult to plan forand pursue — process-internal options (see Similä [56] for evidence of this in the Finnish pulp and paper industry). Nevertheless, process-internal technology has a greater potential for combining cost savings and emissions reduction, e.g., by avoiding the add-on cost of operating the end-of-pipe technology and offering opportunities for material and energy efficiency savings. In this respect, the development of alternative bleaching technologies represents a particularly interesting case study, which is discussed in the next sub-section. In fact, an important reason for the research interest in this particular development has been that it represents processinternal technology; previous research on regulation-induced green technological development has otherwise had a significant bias towards the study of end-of-pipe technologies [68].

\section{The Transition Towards Chlorine-Free Pulp Production}

While pressures from consumers and the public played a role in the pulp and paper industry's transition to chlorine-free pulp production, recent research shows that this role has often been 
overrated in previous literature. As noted above, the consumer market for chlorine-free paper products emerged in the late 1980s following the news that dioxins would be formed also in the manufacturing of bleached chemical pulp [44]. Bergquist and Söderholm [51] show, though, that at this point in time, long-term collaborative $R \& D$ activities in the Swedish pulp and paper industry, largely induced by earlier regulations and perceived cost savings, had already resulted in important technological advances in alternative bleaching technologies. These technological solutions could then constitute the basis for new regulatory conditions. In fact, only a few months after the dioxin alarm broke in 1986, negotiations were underway for the introduction of new, technologyforcing standards on Swedish pulp and paper mills [14••]. In other words, these regulations preceded rather than trailed the increase in consumer demand for chlorine-free paper products. As pointed out below, the more stringent performance standards induced not only technology adoption but also innovation in alternative bleaching technologies and particularly so in Sweden.

Existing literature shows that the alternative bleaching technologies diffused earlier and more rapidly in the Nordic countries, especially in Sweden, compared to North America (e.g., [46]). Bergquist and Söderholm [51] contrast the transition to chlorine-free pulp production in the Swedish and the US pulp and paper industries and conclude that the tradition of technology-based standards in the USA resulted in a situation where the country's pulp mills were locked-in to end-of-pipe abatement technologies (see also [4]). Other studies have also pointed out that even though performance standards could be used in the US system, they typically did not involve long-term targets [43]. In contrast, the capacity of the Swedish pulp and paper mills to respond effectively to the dioxin alarm was underpinned by the country's regulatory strategy to facilitate process-internal changes in the industry. This was achieved through the combination of gradually tightening standards, long-term targets, and extended compliance periods $[3,14 \bullet \cdot]$.

Finally, recent research also puts in doubt the bundling of the Nordic countries in the chlorine transition process. The pulp and paper industries in both Sweden and Finland have constituted cornerstones in the respective economies [69], and both countries have earned an international reputation when it comes to taking the lead in reducing environmentally harmful industrial emissions into air and water. Still, Finland moved more slowly than Sweden with respect to the reduction of chlorine compounds [14••]. Such substances were not even mentioned in Finnish licensing conditions before 1989, at the time when targets for AOX emissions already had been set in Sweden [70]. In Finland, more stringent standards were introduced first in 1993.

\section{The Regulation of Carbon Dioxide Emissions}

While the above investigations have had a strong focus on performance standards regulating the emissions of local pollutants, it is important to recognize that climate policies now play an increasingly important role for the pulp and paper industry. These policies are generally of a relatively recent date, e.g., the EU ETS was launched in 2005, but the global pulp and paper industry achieved quite substantial carbon dioxide emission reductions already during the 1980s following the oil crises in the 1970s. These reductions were achieved through the substitution of electricity and biomass for oil as well as through improved energy efficiency [71].

Climate policies come in many forms, such as support schemes for renewable energy sources, which have benefitted investments in biomass-based electric power generation in the Nordic pulp and paper industries (e.g., [6]). The most direct way of regulating carbon dioxide emissions, however, has been the use of taxes or tradable emissions allowance schemes. For instance, prior to the introduction of EU ETS, Sweden introduced a tax on carbon dioxide emissions, and this has contributed to carbon dioxide reductions in the country's pulp and paper industry [72, 73]. Interestingly, carbon intensity performance responded both to changes in the carbon tax and the fossil fuel price but was more sensitive to the tax, thus suggesting the presence of a signaling effect from the tax.

When introduced in 2005, the EU ETS was the first EUwide regulation of carbon dioxide emissions from the pulp and paper (and other energy-intensive) industries in the Member States. Still, the effectiveness of this scheme in terms of providing incentives for significant emission reductions has overall been low, much due to low allowance prices during extended periods. Evidence of this has been reported for, for instance, the pulp and paper industries in Germany, Norway, and Sweden $[7,74 \cdot, 75]$. In fact, the most profound impact of EU ETS on the industry has been in terms of increased wholesale electricity prices [6]. So far, however, the European pulp and paper industries have primarily focused on incremental improvements in operations rather than on more radical, long-term zero-carbon solutions (see also [76]).

Finally, stringent regulations of carbon dioxide emissions in the US pulp and paper industry essentially do not exist. In the USA, proposals for a national emissions trading scheme in carbon dioxide (e.g., the so-called Waxman-Markey bill) failed to gain support in the Congress, and instead, the U.S. Environmental Protection Agency (EPA) has made efforts to implement (tradable) performance standards for carbon dioxide within the realms of the existing regulatory regime, the Clean Air Act [77]. However, this approach has now resulted in a legal battle in which the US industry and trade associations argue that the U.S. EPA lacks the authority for pursuing this regulation. 


\section{Environmental Regulation, Competiveness, and Technological Change}

The strong and the weak versions of the Porter hypothesis have constituted an important point of departure for previous research on the relationship between environmental regulation and competitiveness in the pulp and paper industry. In this section, we review this research in the context of pulp and paper production, focusing on the impact of regulations on the following: (a) productivity and profits (the strong version) and (b) technological innovation (the weak version).

\section{Environmental Regulation and Productivity}

Empirical studies of the strong version of the Porter hypothesis have primarily used quantitative data, e.g., at mill-, company-, or industry-level, to investigate the relationship between the stringency of various environmental regulation and productivity, profits, and/or efficiency (e.g., [21, 23]). Regulatory stringency is operationalized in different ways, such as using data on emission limit values or estimates of pollution abatement costs. For instance, in a study on the US pulp and paper industry [78], the authors report negative consequences of environmental regulation - in this case measured as pollution abatement costs - on total factor productivity (TFP). Related empirical applications, using plant-level data, exist also for the Nordic countries [79, 80, 81•], some focusing on TFP development and others on changes in profitability. Another strand of research has employed aggregate data at the industry level for EU Member States [82, 83]. The results are overall mixed, some suggesting that there is negative relationship between existing regulations and productivity/profits (e.g., [79, 82]) while others report a corresponding positive (or non-significant) relationship [81, 83].

The state-of-the art research typically adopts a so-called parametric distance function approach, which assumes that pulp and paper mills are multi-output units, thus generating both "goods" (pulp and paper) and "bads" (emissions). This approach permits the estimation of the "shadow price" of pollution, i.e., the change in revenues due to constraints associated with, for instance, emission limit values [21]. A negative shadow price indicates increased costs associated with a more stringent environmental regulation (and vice versa). Another advantage of this approach is that companies are allowed to be inefficient in their use of productive resources, implying that one can also study the correlation between efficiency and environmental regulations.

Two early studies apply the distance function approach in the empirical contexts of the Finnish and Swedish pulp and paper industries, respectively $[84,85]$. These both focus on the regulation of the emissions of BOD agents in water bodies and conclude that the resulting emissions reductions were associated with net costs for the affected companies. Hence, this indicates a rejection of the strong version of the Porter hypothesis. This result has overall been confirmed in several more recent studies on the North American and the Nordic pulp and paper industries, both concerning the regulation of local pollutants and the pricing of carbon dioxide emissions [86-90]. One reason for this is that environmental regulations do not only incur costs in terms of pollution abatement equipment; the compliance process also involves significant transaction costs that divert time and energy away from productive activities (see [91] for a discussion of such costs in the US pulp and paper industry).

Still, there are exceptions to the findings that reject the strong Porter hypothesis. For instance, in a recent study, the authors employ a distance function approach to the German manufacturing industry and conclude that the EU ETS increased the economic performance (in their case efficiency) of regulated firms in the paper industry [92].

\section{Environmental Regulation and Technological Innovation}

Even though there is meager empirical evidence in support of the strong Porter hypothesis in the pulp and paper industry, there is also little suggesting that environmental regulations have (so far) had profound adverse effects on industrial competitiveness; this result holds true also for other industrial sectors [93•]. There are likely several reasons for this. One is simply that the existing regulations have not been stringent enough to generate very negative impacts on productivity and/or employment. For instance, the so-called Cluster Rule in the USA, i.e., the country's first integrated multimedia (air and water) regulation aiming at toxic releases from pulp and paper mills, has only had modest impacts on labor demand in the industry [e.g., 94]. Another reason is that regulations have influenced not only the adoption of existing pollution abatement technologies but also the innovation and the development of new and improved green technologies, in turn lowering the total costs of complying with existing and future regulations. This signifies the weak version of the Porter hypothesis for which there is plenty of support in the empirical context of the pulp and paper industry (see $[14 \bullet \cdot, 24,26,60 \bullet \cdot$ and below).

The fact that the empirical evidence typically rejects the strong version of the Porter hypothesis, when at the same time indicating plenty of support for the weak version, should not come as a big surprise. In an industry, there are likely to exist several-not yet identified - productivity-enhancing measures that could be undertaken if the companies allocated enough resources (e.g., staff hours, pilot plant tests) to search for these. The weak version builds on the far from controversial notion that such search efforts, guided by the environmental regulations, will generate new ideas and solutions. The strong version, though, rests on the notion that these same 
search efforts will generally lead to larger total productivity improvements compared to the corresponding search efforts that companies would have pursued in the absence of the same regulations.

Over the past 45 decades, several important technological developments resulting in environmental improvements have emerged, e.g., increasing the dry content of black liquor, biological and tertiary wastewater treatment (such as activated sludge treatment), and chlorine-free bleaching [24]. In fact, since the 1980s, the industry has witnessed the growing importance of environmental issues as one of the dominant factors stimulating technological innovation [95]. Overall, process innovation has been more important than product innovation [26].

Several of the Finnish case studies address the innovation impacts of the regulation of the pulp and paper industry. This research shows that the country's performance standards during the 1990s contributed to the development of and improvements in clean technologies, e.g., the activated sludge technology [24]. Kivimaa [26] notes that a prerequisite for this development, in Finland as well as in the Nordics as a whole, was the introduction of gradually tightening and predictable standards that spurred the exploration of new technological developments. Still, the innovation impacts were generally more significant with respect to end-of-pipe technology compared to process-internal technology [56]. One reason for this is that the (long-term) targets were not always stringent enough to encourage the development of process-internal solutions [57].

The existence of regulation-induced environmental innovation has been even stronger in the Swedish pulp and paper industry. This is reflected in two recent quantitative studies [60••, 96]; both reports support for the weak Porter hypothesis and relate this to the flexible Swedish regulatory approach involving a mix of flexible, long-term standards and the use of extended compliance and probation periods. Qualitative country case studies confirm this result [2, 58, 97], and these emphasize that the involvement of Swedish government authorities and publicly funded research institutes in industrywide R\&D projects and facilitated the development of process-internal abatement technology. In particular, Swedish pulp producers pioneered the development of several core process technologies for chlorine bleaching during the 1970s and 1980s, including oxygen delignification, advanced batch cooking, and ozone bleaching $[4,98]$.

The development of a green innovation system in the Swedish pulp and paper industry stands out in an international comparison [14••, 27, 51]. For instance, Smith [99] notes that during the 1990s, shared and centralized research in the US pulp and paper industry was limited, as was joint governmentindustry research projects. This, Smith argues, handicapped environmental innovation activities in US industry. A similar observation can be made in relation to Finland. Compared to Sweden, joint green $R \& D$ projects have been fewer in the
Finnish pulp and paper industry, in part due to a more diversified and value-added product mix [14••]. The Swedish industry has instead been more homogenous with large-scale production of low value-added products such as sulfate pulp. For this reason, the Swedish pulp and paper mills faced similar problems and the same regulatory pressure; it therefore made sense to share the risks and costs involved in the greening of their production processes [97]. Herbert-Copley [63] argues that collaborative R\&D was important for the adoption of alternative bleaching technologies also in the Canadian pulp and paper industry.

Finally, while the above illustrates that environmental regulation has had profound impacts on green innovations in the pulp and paper industry, we see much more limited evidence of policy-induced innovation in the climate field, e.g., as a result of EU ETS. A few industry case studies addressing the innovation impacts of the EU ETS exist, including empirical research on the pulp and paper industries in Germany [75], Italy [100], and Sweden [101•]. In Sweden, both the domestic carbon dioxide tax and, thereafter, the EU ETS only imposed low carbon prices, thus resulting in modest innovation impacts. The German study uses survey data and concludes that innovation activities in the pulp and paper industry have mainly been influenced by market developments; the EU ETS (and other climate policies) only had modest innovation impacts [75]. These impacts were also lower for the technology providers than for the pulp and paper producers. Nevertheless, the majority of the German pulp and paper companies expected the stringency of the regulatory climate policy framework on innovation to increase by 2020 and onwards. Gulbrandsen and Stenqvist [74•] discuss these results and argue that the reliance of survey data may miss critical aspects of corporate responses to the EU ETS.

This section has illustrated how the same type of policy instrument, i.e., performance standards, will interact with other policies (e.g., R\&D support), as well as be embedded in various complex institutional and organizational arrangements that often have evolved over long time periods. This will in turn generate different outcomes in terms of the adoption and development of green technology. This conclusion gains support in a Dutch review of previous research addressing the relationship between environmental policy instruments and innovation in the pulp and paper industry [102]. It is also worth mentioning that while the existing theoretical literature typically concludes that pollution taxes and tradable emission allowance schemes are superior in terms of promoting innovation [103], the empirical evidence is in fact mixed. The experiences from the pulp and paper industry instead suggest that ambitious performance standards and extended compliance periods could provide profound incentives for technological change and innovation, while at the same time avoiding excessive compliance costs for competitive industrial sectors in the short-term. In fact, economic policy instruments, such 
as carbon pricing, have so far been less successful from this perspective.

\section{The Institutional Context for Decision-Making}

It should be clear that regulatory approaches to industrial pollution go beyond just identifying individual policy instruments, e.g., taxes or performance standards. As illustrated above, these approaches also concern the design of instruments, such as flexibility in terms of technological choice and time of compliance, as well as the existence of complementing instruments, such as public funding of green R\&D projects and demonstration plants. The latter will be particularly important for achieving radical emission reductions through knowledge accumulation and transfer. In this section, we review research that has provided evidence of the importance of the entire set up of the regulatory system, such as emphasizing the role of informal norms, forms of relationship between regulators and industry, and social trust.

Previous research confirms that countries tend to have different regulatory styles and cultures in the environment field [104]. Distinct national institutions, including historically shaped firm-government relations, will contribute to specific contexts for implementation of environmental regulations. This is particularly important given that such regulations, including performance standards, normally are the outcome of case-by-case licensing procedures, thus involving direct negotiations between the regulator and the industrial polluter.

Empirical studies show that such institutional factors have influenced how the pulp and paper industries in various countries have responded to environmental regulations. In one study of the environmental performance of a number of pulp and paper mills in Australia, Canada, New Zealand, and the USA, the authors attempt to link the outcomes to various observable factors, including corporate management and the stringency of regulations [5]. Still, they conclude that differences in these factors across the mills could only provide a partial explanation to the environmental outcomes; many unobserved factors, such as regulatory styles and the form of firm-regulator negotiations, could be just as important.

Several studies investigating the Swedish pulp and paper industry have argued that its specific contextual and historically shaped conditions in many ways facilitated the transition to deep emissions reductions $[3,14 \cdot \bullet, 46]$. In the previous section, we emphasized how this transition relied on, for instance, the involvement of government in industry-wide R\&D projects, long-term emissions reduction targets, and the use of extended compliance periods. However, this regulatory approach would not have been possible, it is argued, without the consensual and expert-dominant regulatory style dominating in Sweden, in particular during the 1970s and the 1980s [27].
One key illustration of this is the sharing of information among actors (e.g., about best available technology), in turn implying that new knowledge was advanced jointly and incrementally in close interaction between the pulp and paper industry, the environmental authorities, and the research institutions before the final performance standards were determined [27]. The Swedish approach also rested on high regulatory competence (e.g., participation of industrial engineers in the licensing committee's), in turn implying that the extent of firm-regulator information asymmetries was relatively limited [3]. As a result, increasingly stringent regulations could be introduced gradually without jeopardizing the long-run competitiveness of the industry. The importance of high regulatory competence is addressed also in a case study of the Norwegian pulp and paper industry [59]; this author concludes that a common understanding between the regulatory authority and the affected firms - not least about the environmental problems and its possible solutions - is a prerequisite for a successful green industrial transition.

As noted above, environmental regulations developed earlier and more consistently in Sweden compared to Finland, e.g., as illustrated in the countries' responses to the dioxin alarm in the end of the 1980s [14*0]. This heterogeneity across the two countries can in part be traced to political culture and power relations. In Finland, the pulp and paper industry gained significant political power during the twentieth century; its interests became more or less synonymous with the general national interest [105]. Environmental pollution issues became rather politicized, in part due the political divide between rural-based and urban-based interests [106], and this delayed the introduction of a central administrative body that could address environmental regulation of the industry. In Sweden, though, the cooperative approach led to a more pragmatic political solution on how to address the industrial pollution problems by developing the existing industry structures through a combination of efficient environmental regulations and public funding of environmental R\&D [14••]. The role of power and influence in understanding the impacts of environmental regulation is also addressed in a study of the Canadian pulp and paper industry over a 20-year period [107].

Both Reinstaller [46] and Bergquist and Söderholm [51] argue that the relative efficiency of the flexibility in the Swedish regulatory approach relied on a high level of trust between the regulator and the polluting firms. The issue of trust in business-government relations is also raised by Bouvier [108], who examines the regulation and environmental performance among eight pulp and paper mills in the state of Maine, USA. She concludes that the regulations, even if well-crafted, were partially undermined by the historically very powerful position of the pulp and paper industry in the region. Improving the relationship and trust between the regulatory agency's officers and the environmental managers can bring about a better understanding of the intent of the legal 
requirements, help find least-cost ways to achieve compliance, and reduce the sometimes antagonistic and confrontational atmosphere between these actors.

\section{Discussion and Implications}

In this article, we have synthesized lessons from previous research on the role of environmental regulation in (a) providing incentives for emissions reductions in the pulp and paper industry, (b) permitting environmental compliance without jeopardizing long-run competitiveness, and (c) inducing technological change and innovation that help reduce the costs of complying with increasingly stringent regulations.

At a general level, our review of existing empirical research, involving qualitative as well as quantitative studies, illustrates the complex economic and institutional mechanisms through which environmental compliance and innovation tend to develop. The debate about the role of environmental regulation in the greening of industry therefore needs to abstain from simplified normative notions about policy instrument choices (e.g., performance standards versus taxes) regardless of context. Regulatory designs, implementation strategies, and various institutional preconditions (e.g., social trust) will matter just as much. For instance, even though the existing economic-theoretical literature argues that pollution taxes and tradable emission allowances are superior to performance standards in promoting innovation, the experiences from the (Nordic) pulp and paper show evidence of performance standards promoting technological innovation.

In addition, in the case of environmental requirements that emerge from case-by-case licensing procedures, there is normally no simple, one-directional (stimulus-response) link between the regulator and the affected industry. Firms' compliance and technology adoption strategies will also be affected by multiple policies. The Swedish case studies illustrate the above points. The cooperative approach of sharing information implied that new knowledge was advanced jointly in close interaction between industry, environmental authorities, and research institutes before the final license was issued. Joint public-private $R \& D$ efforts were encouraged to develop and improve abatement technologies.

While this article primarily has discussed the experiences from past green transitions in the industry, it is important to recognize that today the global pulp and paper industry faces new challenges. These are related to the transition to a biobased economy [e.g., 109-111], in which biological resources could contribute to carbon dioxide mitigation, circularity of resources, as well as offer new and better functions (e.g., higher stability, longer lifetimes, less toxicity). For instance, the European Union's so-called Bioeconomy Strategy endorses the development of novel biorefinery concepts [112]. These value chains involve not only the production of second- and third-generation biofuels for transportation purposes but also green chemicals and new materials from forest raw materials (replacing fossil fuel-based products) [13].

This development implies new types of challenges, including the establishment of new business models and value chains [12]. Even though these challenges have not been directly addressed in this article, our review of existing research carries at least two important lessons for the ongoing bioeconomy development. First, the more radical greening of industrial processes for the production of a wider set of final products will be characterized by long development periods during which new technology-specific systemic structures, e.g., actor networks and institutions, need to be established. We have illustrated that the pulp and paper industry's efficient response to the environmental concerns emanating from the emissions of chlorine compounds was possible in part because the necessary green innovation system had already been put in place $[27,51]$. The development of forest-based biorefineries will also require a mix of traditional regulations (and/or taxes) combined with deliberate public efforts to support R\&D and various pilot and demonstration projects $[113,114]$.

Second, the implementation of stricter environmental regulations, such as the relatively recent EU directive on sulfur emissions, is likely to shape the future of the pulp and paper industries in all parts of the world. As noted in the introduction to this article, such tightening regulations may pose both an opportunity and a threat to future sustainability transitions in the industry. For this reason, it is important to identify regulations that can facilitate future sustainability transitions (e.g., deep emission reductions, novel green value chains) without at the same time jeopardizing the competitiveness of the industry. Our review has shown that such green transitions have taken place without imposing excessive compliance costs and even permitting increased production. The environmental regulations that have made this possible typically possess a number of key characteristics. These include firm flexibility in terms of compliance measures, industry-wide $R \& D$ cooperation, knowledge transfer between public R\&D support and technology adoption choices at the firm level, the use of extended compliance periods to permit experimentation, and high regulatory competence. In addition, in order to gain market benefits from the greening of the forest raw material supply chain, further attention should also be devoted to the complementary roles of traditional regulations on the one hand and voluntary initiatives on the other $\left[10^{\bullet} \cdot\right]$.

\section{Conclusions}

Following the above, it should be clear that there is plenty of scope for additional conceptual and empirical research on the role of environmental regulations, including climate policies, 
in the global pulp and paper industry. We emphasize three important avenues for future research.

First, as shown above, the impacts of these regulations are highly dependent on the institutional context. Still, there is a need for comparative research addressing how the policy mixes of various countries have influenced the processes of environmental compliance and innovation in the industry. In fact, industry will often have to confront both emissions standards and taxes (or emission allowance schemes) at the same time. Furthermore, while it is virtually impossible to present a unanimous ranking of various types of regulations, e.g., performance standards versus technology standards (and pollution taxes), with respect to their innovation-stimulating effects, comparative research is needed to shed additional light on the importance of various regulatory designs and implementation strategies. In-depth historical studies are typically particularly well-suited in filling these research gaps by detecting the complexities within which environmental regulation and related contextual factors have been translated into variations of firm-level strategies, both among incumbents and new actors. The pulp and paper industry is particularly capital intensive, and pursuing radical technological shifts through R\&D or even the adoption of off-the-shelf technologies in this industry takes time due to path dependencies and institutional lock-in. For this reason, studies of regulationinduced technological change often require a historical (long-term) perspective.

Second, so far, the existing empirical research has had a strong bias towards the Nordic countries and North America. Still, the global pulp and paper industry has changed significantly during the last decades, not least in terms of its innovation dynamics. The industry has witnessed the emergence of new actors in South America (Brazil) and Asia (China) and on top of that a lack of focused value chain strategies among the traditional companies in the Nordics and in North America (e.g., [12]). Future research should address the role of environment regulation in these emerging countries, including how regulations have been - and still are - shaped by various institutional preconditions and constraints. The latter is important for our understanding of the extent to which key policy lessons from Europe and North America can be transferred to other countries and vice versa.

Third and finally, there is a need for new research on how to choose, design, and implement environmental regulations that can provide incentives for efficient transitions to sustainable production processes and products without however jeopardizing the competiveness of the industry. While this article has pin-pointed a number of lessons from previous green transitions, it is essential to consider in more detail how future - and in part already ongoing - restructurings of the pulp and paper industry towards a broader palette of products in biorefineries could be affected by environmental regulation and other policies. As emphasized above, well-designed and legitimate regulations could support these restructuring processes while regulations that are poorly designed and lack a recognition of the institutional context may instead pose threats.

Acknowledgments Research funding from the Swedish Energy Agency and the Swedish Research Council Formas is gratefully acknowledged as is valuable support from the journal's managing editor. Any remaining errors reside solely with the authors.

Funding Information Open access funding provided by Lulea University of Technology.

\section{Compliance with Ethical Standards}

Conflict of Interest Patrik Söderholm, Ann-Kristin Bergquist, and Kristina Söderholm declare that they have no conflict of interest.

Human and Animal Rights This article does not contain any studies with human or animal subjects performed by any of the authors.

Open Access This article is distributed under the terms of the Creative Commons Attribution 4.0 International License (http:// creativecommons.org/licenses/by/4.0/), which permits unrestricted use, distribution, and reproduction in any medium, provided you give appropriate credit to the original author(s) and the source, provide a link to the Creative Commons license, and indicate if changes were made.

\section{References}

Papers of particular interest, published recently, have been highlighted as:

- Of importance

•• Of major importance

1. Bajpai P. Environmentally friendly production of pulp and paper. Hoboken: John Wiley \& Sons; 2010.

2. Bergquist AK, Söderholm K. The greening of the pulp and paper industry: Sweden in comparative perspective. In: Särkkä T, Gutiérrez-Posh M, Kuhlberg M, editors. Technological transformation in the global pulp and paper industry 1800-2018, vol. 6587: Springer. p. 2018.

3. Bergquist AK, Söderholm K, Kinneryd H, Lindmark M, Söderholm P. Command-and-control revisited: environmental compliance and technological change in Swedish industry, 1970-1990. Ecol Econ. 2013;85:6-19.

4. Harrison K. Ideas and environmental standard-setting: a comparative study of regulation of the pulp and paper industry. Governance: An International Journal of Policy, Administration and Institutions. 2002;15(1):65-96.

5. Gunningham N, Kagan RA, Thorton D. Different shades of green: business, regulation and environment: Stanford University Press; 2003.

6. Ericsson K, Nilsson LJ, Nilsson M. New energy strategies in the Swedish paper and pulp industry - the role of national and EU climate and energy policies. Energy Policy. 2011;39:1439-49.

7. Gulbrandsen LH, Stenqvist C. The limited effect of EU emissions trading on corporate climate strategies: comparison of a Swedish and a Norwegian pulp and paper company. Energy Policy. 2013;56: 516-25. 
8.• Bergquist AK, Keskitalo CH. Regulation versus deregulation: policy divergence between Swedish forestry and Swedish pulp and paper industry after the 1990s. Forest Policy Econ. 2016;73:10-7 Discusses and attempts to explain the divergence of environmental regulation in the pulp and paper industry in relation to the closely linked forestry sector. In the former case, environmental regulations have been more stringent, in part facilitated by the alignment of environmental protection and production growth through technological change.

9. King A, Prado AM, Rivera J. Industry self-regulation and environmental protection. In: Bansal P, Hoffman AJ, editors. Oxford Handbook in Business and the Environment. Oxford: Oxford University Press; 2012. p. 103-21.

$10 . \bullet$ Korhonen J, Pätäri S, Toppinen A, Tuppura A. The role of environmental regulation in the future competitiveness of the pulp and paper industry: the case of the sulfur emissions directive in Northern Europe. J Clean Prod. 2015;108:864-72 Makes use of a panel of experts to analyze the effectiveness of environmental regulation with emphasis on its role for pursuing future sustainability transitions in the industry. Stringent regulations can be both a threat and an opportunity, in turn suggesting the important role of efficient implementation of policies.

11. Mossberg J, Söderholm P, Hellsmark H, Nordqvist S. Crossing the biorefinery valley of death? Actor roles and networks in overcoming barriers to a sustainability transition. Environ Innov Soc Trans. 2018;27:83-101.

12. Pätäri S, Kylaheiko K, Sandström J. Opening up new strategic options in the pulp and paper industry: case biorefineries. Forest Policy Econ. 2011;13(6):456-64.

13.• Hansen T, Coenen L. Unpacking resource mobilisation by incumbents for biorefineries: the role of micro-level factors for technological innovation system weaknesses. Tech Anal Strat Manag. 2017;29(5):500-13 Investigates the limited adoption of biorefinery technology in the Nordic pulp and paper industries and attributes this to lack of competence and partnerships. Different strategies for improving resource mobilization in the industry are identified and discussed.

14.• Söderholm K, Bergquist AK, Söderholm P. The transition to chlorine free pulp revisited: Nordic heterogeneity in environmental regulation and R\&D collaboration. J Clean Prod. 2017;165: 1328-39 This article contradicts earlier research by illustrating that the transition to chlorine-free pulp production in the Nordic countries was induced by gradually tightening performance standards. It identifies important differences between Finland and Sweden in this process, such as the Swedish history of industry-wide cooperation in environmental R\&D.

15. Ruth M, Davidsdottir B, Laitner S. Impacts of market-based climate change policies on the US pulp and paper industry. Energy Policy. 2000;24(8):259-70.

16. Thollander P, Ottosson M. An energy efficient Swedish pulp and paper industry - exploring barriers to and driving forces for costeffective energy efficiency investments. Energy Efficiency. 2008;1(1):21-34.

17. Henriksson E, Söderholm P, Wårell L. Industrial electricity demand and energy efficiency policy: the role of price changes and private R\&D in the Swedish pulp and paper industry. Energy Policy. 2012;47(1):437-46.

18. Laplante B, Rilstone P. Environmental inspections and emissions of the pulp and paper industry in Quebec. J Environ Econ Manag. 1996;33:331-60.

19. Nentjes A, de Vries FP, Wiersma D. Technology-forcing through environmental regulation. Eur J Polit Econ. 2007;23:903-16.

20. Sandén B, Azar C. Near-term technology policy for long-term climate targets. Economy-wide versus technology specific approaches. Energy Policy. 2005;33:1557-76.
21. Brännlund R, Lundgren T. Environmental policy without costs? A review of the Porter hypothesis. Int Rev Environ Resour Econ. 2009;3(2):75-117.

22. Porter ME, van der Linde C. Toward a new conception of the environment-competitiveness relationship. J Econ Perspect. 1995;9:97-118.

23. Ambec S, Cohen MA, Elgie S, Lanoie P. The Porter hypothesis at 20: can environmental regulation enhance innovation and competitiveness. Rev Environ Econ Policy. 2013;7(1):2-22.

24. Mickwitz P, Hyvättinen H, Kivimaa P. The role of policy instruments in the innovation and diffusion of environmentally friendlier technologies: popular claims versus case study experiences. $\mathbf{J}$ Clean Prod. 2008;16S1:S162-70.

25. Kemp R, Pontoglio S. The innovation effects of environmental policy instruments - a typical case of the blind men and the elephant. Ecol Econ. 2011;72:28-36.

26. Kivimaa P. The determinants of environmental innovation: the impacts of environmental policies on the Nordic pulp, paper and packaging industries. Environ Policy Gov. 2007;17:92-105.

27. Bergquist AK, Söderholm K. Green innovation systems in Swedish industry, 1960-1989. Bus Hist Rev. 2011;85(4):677-98.

28. Gunningham N. Corporate environmental responsibility: law and the limits of voluntarism. In: McBarnet D, Voicules A, Campbell $\mathrm{T}$, editors. The new corporate accountability: corporate social responsibility and the law. Cambridge: Cambridge University Press; 2007. p. 476-500.

29. Lennox MJ, Nash J. Industry self-regulation and adverse selection: a comparison across four trade association programs. Bus Strateg Environ. 2003;12:343-56.

30. Delmas M, Montiel I. The diffusion of voluntary international management standards: responsible care, ISO 9000, and ISO 14001 in the chemical industry. Policy Stud J. 2008;36(1):65-93.

31. King A, Toffel MW. Self-regulatory institutions for solving environmental problems: perspectives and contributions from the management literature. In: Delmas M, Young O, editors. Governing the environment: interdisciplinary perspective. Cambridge: Cambridge University Press; 2009.

32. Short JL, Toffel MW. Making self-regulation more than merely symbolic: the critical role of legal enforcement. Adm Sci Q. 2010;55:361-9.

33. Sinclair D. Self-regulation versus command and control? Beyond false dichotomies. Law \& Policy. 1997;19(4):529-59.

34. King A, Lennox M. Industry self-regulation without sanctions: the chemical industry's responsible care program. Acad Manag J. 2000;43(4):698-716.

35. Delmas M. The diffusion of environmental management standards in Europe and the United States: an institutional perspective. Policy Sci. 2002;35(1):91-119.

36. Prakash A, Potoski M. The voluntary environmentalists: green clubs, ISO 14001 and voluntary environmental regulations. Cambridge: Cambridge University Press; 2006.

37. Keskitalo ECH, Sandström C, Tysiachnouk MS, Johansson L. Local consequences of applying international norms: differences in the application of forest certification in northern Sweden, northern Finland and Northwest Russia. Ecol Soc. 2009;14(2):1.

38. Overdevest C. Comparing forest certification schemes: the case of ratcheting standards in the forest sector. Soc Econ Rev. 2009;8(1): 47-76.

39. Rametsteiner E, Simula M. Forest certification - an instrument to promote sustainable forest management? J Environ Manag. 2003;67(1):87-98.

40. Gunningham N, Sinclair D. Regulatory pluralism: designing policy mixes for environmental protection. Law \& Policy. 1999;21: 49-76. 
41. Barla P. ISO 14001 certification and environmental performance in Quebec's pulp and paper industry. J Environ Econ Manag. 2007;53(3):291-306.

42. Söderholm K. Environmental awakening in the Swedish pulp and paper industry: pollution resistance and firm responses in the early 20th century. Bus Strateg Environ. 2009;18:32-42.

43. Norberg-Bohm V, Rossi M. The power of incrementalism: environmental regulation and technological change in pulp and paper bleaching in the US. Tech Anal Strat Manag. 1998;10(2):225-45.

44. Popp D, Hafner T, Johnstone N. Environmental policy vs. public pressure: innovation and diffusion of alternative bleaching technologies in the pulp industry. Res Policy. 2011;40:1253-68.

45. Rajotte A. Paper production technology and environmental performance in Sweden and Finland: policy, science and market share. Soc Nat Resour. 2003;16(8):719-28.

46. Reinstaller A. The technological transition to chlorine free pulp bleaching technologies: lessons for transition policies. J Clean Prod. 2008;16:133-47.

47. Reinstaller A. Policy entrepreneurship in the co-evolution of institutions, preferences and technology: comparing the diffusion of totally chlorine free pulp bleaching technologies in the US and Sweden. Res Policy. 2005;34:1366-84.

48. Sonnenfeld DA. Social movements and ecological modernization: transformation of the pulp and paper industry. Dev Chang. 2002;33:1-27.

49. Sonnenfeld DA. Vikings and tigers: Finland, Sweden and the adoption of environmental technologies in South Asia's pulp and paper industry. Journal of World-Systems Research. 1999;5:26-47.

50. Schneider TE. Is there a relation between the cost of debt and environmental performance? An empirical investigation of the U.S. pulp and paper industry. Ph.D. dissertation. Canada: University of Waterloo; 2008.

51. Bergquist AK, Söderholm K. Transition to greener pulp: regulation, industry responses and path dependency. Bus Hist. 2015;57(6):862-84.

52. Mickwitz P. Is it as bad as it sound or as good as it looks? Experiences of Finnish water discharge limits. Ecol Econ. 2003;45:237-54.

53. Söderholm K, Söderholm P, Gustafsson S, Sundin T. Miljöprövningens roll för industrins utsläppsreduktion: erfarenheter från svenska pappers- och massabruk, 1981-2013. In: Darpö J, Forsberg M, Pettersson M, Zetterberg C, editors. Miljörätten och den förhandlingsovilliga naturen. Uppsala: Iustus förlag; 2019. p. 355-74.

54. Brännlund R, Löfgren KG. Emission standards and stochastic waste load. Land Econ. 1996;72(2):218-30.

55. McClelland JD, Horowitz JK. The costs of water pollution regulation in the pulp and paper industry. Land Econ. 1999;75(2):220-32.

56. Similä J. Pollution regulation and its effects on technological innovations. J Environ Law. 2002;14(2):143-60.

57. Hilden M, Lepola J, Mickwitz P, Mulders A, Palosaari M, Similä $\mathrm{J}$, et al. Evaluation of environmental policy instruments: case study of the Finnish pulp \& paper and chemical industries, Monographs of the boreal environmental research 21. Helsinki: Finnish Environment Institute; 2002.

58. Söderholm K, Bergquist AK. Growing green and competitive - a case study of a Swedish pulp mill. Sustainability. 2013;5:1789-805.

59. Saether B. Continuity and convergence: reduction of water pollution in the Norwegian paper industry. Bus Strateg Environ. 2000;9:390-400.

$60 . \bullet$ Weiss JF, Stephan A, Anisimova T. Well-designed environmental regulation and firm performance. Swedish evidence on the Porter hypothesis and the effect of regulatory time strategies. J Environ Plan Manag. 2019;62(2):342-63 Employs data for a cross section of Swedish pulp and paper firms and provides quantitative evidence of the link between environmental regulations and innovation at the firm level. The results highlight the importance regulatory time strategies (compliance periods) and public funding of R\&D.

61. Gray WB, Shadbegian RJ. Environmental regulation, investment timing, and technology choice. J Ind Econ. 1998;46(2):235-56.

62. Doonan J, Lanoie P, Laplante B. Determinants of environmental performance in the Canadian pulp and paper industry: an assessment from inside the industry. Ecol Econ. 2005;55:73-84.

63. Herbert-Copley B. To the limits... and beyond? Environmental regulation and innovation in the Canadian pulp and paper industry. In: Parto S, Herbert-Copley B, editors. Industrial innovation and environmental regulation: developing workable solutions. New York: United Nations University Press; 2007.

64. Ghosal V. Business strategy and firm reorganization: role of changing environmental standards, sustainable business initiatives and global market conditions. Bus Strateg Environ. 2015;24(2): 123-44 Studies pulp and paper mills in Finland, Germany, Sweden, and the USA, and finds important differences across these in terms of their ability to pursue changes in the production processes. The stringent and transparent environmental regulations in the Nordic countries have benefitted the European pulp and paper industry.

65. Xu J, Hyde WF, Amacher GS. China's pulp and paper industry: growth and environmental policy during economic reform. J Econ Dev. 2003;28(1):49-79.

66. Wang Y, Liu J, Hansson L, Zhang K, Wang R. Implementing stricter environmental regulation to enhance eco-efficiency and sustainability: a case study of Shandong Province's pulp and paper industry, China. J Clean Prod. 2011;19(4):303-10.

67. Yu C, Shi L, Wang Y, Chang Y, Cheng B. The eco-efficiency of pulp and paper industry in China: an assessment based on slacksbased measure and Malmqvist-Luenberger Index. J Clean Prod. 2016;127:511-21 This is a recent study of the environmental performance of the rapidly growing Chinese pulp and paper industry. Stricter environmental regulation, e.g., for water pollution, is found to have positive effects on companies' environmental performance.

68. Allan C, Jaffe AB, Sin I. The diffusion of green technology: a survey. Int Rev Environ Resour Econ. 2014;7(1):1-33.

69. Fellman S, Iversen MJ, Sjögren H, Thue L. Creating Nordic capitalism. The business history of a competitive periphery. London: Palgrave; 2008.

70. Auer MR. Krafting an agreement: negotiations to reduce pollution from the Nordic pulp industry, 1985-1989. New Haven: Yale University Press; 1996.

71. Lindmark M, Bergquist AK, Andersson LF. Energy transition, carbon dioxide reduction and output growth in the Swedish pulp and paper industry, 1973-2006. Energy Policy. 2011;39(9):5449-56.

72. Brännlund R, Lundgren T, Marklund P-O. Carbon intensity in production and the effects of climate policy: evidence from Swedish industry. Energy Policy. 2014;67:844-57.

73. Färe R, Grosskopf S, Lundgren T, Marklund P, Zhou W. The impact of climate policy on environmental and economic performance: evidence from Sweden. London: Routledge; 2016.

74. Gulbrandsen LH, Stenqvist C. Pulp and paper industry. In: Skjærseth JB, Eikeland PO, editors. Corporate responses to EU emissions trading: resistance, innovation or responsibility? London: Routledge. This chapter discusses the ability of the EU ETS to influence the climate strategies of major pulp and paper companies in the European Union. This impact has been small, and the authors discuss reasons for this finding (including methodological issues).

75. Rogge KS, Schleich J, Hausmann P, Roser A, Reitze F. The role of the regulatory framework for innovation activities: the EU ETS and the German paper industry. Int J Technol, Policy agement. 2011;11:250-73. 
76. Karltorp K, Sandén B. Explaining regime destabilisation in the pulp and paper industry. Environmental Innovation and Societal Transitions. 2012;2:66-81.

77. Schmalensee R, Stavins RN. Policy evolution under the Clean Air Act. Discussion Paper 2018-93. Harvard Project on Climate Agreements, Harvard University, Cambridge, 2018.

78. Gray WB, Shadbegian RJ. Plant vintage, technology, and environmental regulation. J Environ Econ Manag. 2003;46:384-402.

79. Brännlund R, Färe R, Grosskopf S. Environmental regulation and profitability: an application to Swedish pulp and paper mills. Environ Resour Econ. 1995;6:23-36.

80. Telle K, Larsson J. Do environmental regulations hamper productivity growth? How accounting for improvements of plants' environmental performance can change the conclusion. Ecol Econ. 2007;61:438-45.

81. Ghosal V, Stephan A, Weiss JF. Decentralized environmental regulations and plant-level productivity. Business Strategy and the Environment. 2019; forthcoming. This article studies the impact of environmental regulation on the environmentally adjusted total factor productivity using data for Swedish pulp and paper mills. The results indicate a positive relationship, but primarily in the case of smaller plants.

82. Wagner M, Van Phu N, Azomahou T, Wehrmeyer W. The relationship between the environmental and economic performance of firms: an empirical analysis of the European paper industry. Corp Soc Responsib Environ Manag. 2002;9(3):133-46.

83. Brolund J, Lundmark R. Effect of environmental regulation stringency on the pulp and paper industry. Sustainability. 2017;9:2323 .

84. Hetemäki L. Environmental regulation and production efficiency: evidence from the pulp industry. Helsinki: Finnish Forest Research Institute; 1995.

85. Brännlund R. Estimating shadow prices of undesirables. Department of Economics. Sweden: Umeå University; 1996.

86. Boyd GA, McClelland JD. The impact of environmental constraints on productivity improvement in integrated paper plants. J Environ Econ Manag. 1999;38:121-42.

87. Hailu A. Pollution abatement and productivity performance of regional Canadian pulp and paper industries. J For Econ. 2003;9:5-25.

88. Marklund P-O. Environmental regulation and firm efficiency: studying the Porter hypothesis using a directional output distance function. Umeå Economic Studies No. 619. 2003. Umeå University, Sweden.

89. Lundgren T, Marklund P-O. An analysis of the Swedish CO2 tax and its impact on firm performance. CERE Working Paper 2016:1. Centre for Environmental and Resource Economics. Sweden: Umeå University; 2016.

90. Lundgren T, Marklund P-O. Climate policy, environmental performance, and profits. J Prod Anal. 2015;44(3):225-35.

91. Haight C, Thieme D. Regulation in the pulp and paper industry: costs and consequences. Working Paper No. 12-16. Mercatus Center. Fairfax: George Mason University; 2012.

92. Löschel A, Lutz BJ, Managi S. The impacts of the EU ETS on efficiency and economic performance - an empirical analysis for German manufacturing firms. Resour Energy Econ. 2019;56:71-95.

93. Dechezleprêtre A, Sato M. The impacts of environmental regulations on competitiveness. Rev Environ Econ Policy. 2017;11(2): 183-206 Contains a review of the empirical literature addressing the impacts of environmental regulations on firms' competitiveness. It concludes that there is plenty of evidence for the weak version of the Porter hypothesis but less support for the strong version. Still, impacts are small relative to general trends.

94. Gray WB, Shadbegian RJ, Wang C, Meral M. Do EPA regulations affect labor demand? Evidence from the pulp and paper industry. $\mathrm{J}$ Environ Econ Manag. 2014;68(1):188-202.
95. Collins L. Environmental performance and technological innovation: the pulp and paper industry as a case in point. Technol Soc. 1994; 16(4):427-46.

96. Weiss JF, Anisimova T. The innovation and performance effects of well-designed environmental regulation: evidence from Sweden. Ind Innov. 2019;26(5):534-67.

97. Söderholm K, Bergquist AK. Firm-collaboration and environmental adaptation: the case of the Swedish pulp and paper industry 1900-1990. Scand Econ Hist Rev. 2012;60(2):183-211.

98. Kramer JD. Pulping/bleaching technology view shows North America lagging. Pulp and Paper. 2000;74:51-9.

99. Smith M. The US paper industry and sustainable production. An argument for restructuring. MIT Press, Cambridge, 1997.

100. Pontoglio S. An early assessment of the influence on ecoinnovation of the EU emissions trading scheme: evidence from the Italian paper industry. In: Mazzanti M, Montini A, editors. Environmental efficiency. Innovation and economic performances: Routledge; 2010. p. 81-91.

101. Lundgren T, Marklund P-O, Samakovlis E, Zhou W. Carbon prices and incentives for technological development. J Environ Manag. 2015;150:393-403 Analyzes the impact of the EU ETS and carbon taxes on productivity development in the Swedish pulp and paper industry and finds that these climate policies have only modest impacts on the level of technological development in the industry. This suggests that carbon prices have been low.

102. Kuik, O. Environmental innovation dynamics in the pulp and paper industry. Institute for Environmental Studies (IVM), Vrije University, Amsterdam, 2006.

103. Goulder LH, Parry IWH. Instrument choice in environmental policy. Rev Environ Econ Policy. 2008;2(2):152-74.

104. Löfstedt R, Vogel D. The changing character of regulation: a comparison of Europe and the United States. Risk Anal. 2001;21(3): 399-405.

105. Kettunen P. The Nordic welfare state in Finland. Scand J Hist. 2001;26(3):225-47.

106. Joas M. Finland: from local to global politics. In: Andersen MS, Liefferink D, editors. European environmental policy: the pioneers. Manchester:: Manchester University Press; 1997.

107. Doern GB. Sectoral green politics: environmental regulation and the Canadian pulp and paper industry. Environmental Politics. 1995;4(2):219-43.

108. Bouvier R. Determinants of environmental performance: pulp and paper mills, regulations, and community in Maine. Econ Dev Q. 2009;23(2):111-26.

109. Bugge MM, Hansen T, Klitkou A. What is the bioeconomy? A review of the literature. Sustainability. 2016;8(7):691.

110. Kleinschmit D, Lindstad BH, Jellesmark Thorsen B, Toppinen A, Roos A, Baardsen S. Shades of green: a social scientific view on bioeconomy in the forest sector. Scand J For Res. 2014;29(4):402-10.

111. Pätäri S, Tuppura A, Toppinen A, Korhonen J. Global sustainability megaforces in shaping the future of the European pulp and paper industry towards a bioeconomy. Forest Policy Econ. 2016;66:38-46.

112. Patermann C, Aguilar A. The origins of the bioeconomy in the European Union. New Biotechnol. 2018;40:20-4.

113. Hellsmark H, Frishammar J, Söderholm P, Ylinenpää H. The role of pilot and demonstration plants in technology development and innovation policy. Res Policy. 2016;45:1743-61.

114. Scordato L, Klitkou A, Tartui VE, Coenen L. Policy mixes for the sustainability transition of the pulp and paper industry in Sweden. J Clean Prod. 2018;183:1216-27.

Publisher's Note Springer Nature remains neutral with regard to jurisdictional claims in published maps and institutional affiliations. 